\title{
Odpowiedzi na pytania dotyczące obowiązku odmawiania Liturgii Godzin
}

Codzienne odmawianie całej Liturgii Godzin należy do samej istoty posługi kościelnej, czyli obowiązków, kapłanów i diakonów przygotowujących się do przyjęcia prezbiteratu.

Dlatego mijałby się z prawdą ten, kto uważałby, że odmawianie Liturgii Godzin jest tylko spełnieniem pewnego kanonicznego obowiązku - jaki wprawdzie istnieje - ale nie można nie brać pod uwagę, że mocą sakramentalnego charakteru święceń diakonowi i kapłanowi został powierzony specjalny obowiązek chwalenia Boga Jedynego w Trójcy ze względu na Jego najwyższą dobroć i piękno oraz ze względu na Jego przedziwne i pełne miłosierdzia zamiary dotyczące naszego nadprzyrodzonego zbawienia.

Równocześnie z oddaniem chwały Bożemu Majestatowi, kapłani i diakoni zanoszą prośby, aby Bóg raczył zaspokoić potrzeby duchowe i doczesne Kościoła i całej ludzkości.

„Ofiara uwielbienia” dokonuje się przede wszystkim przez odprawienie Najświętszej Ofiary Eucharystycznej, lecz przygotowuje się i rozciąga się na poszczególne pory dnia przez sprawowanie Liturgii Godzin (por. Ogólne Wprowadzenie do Liturgii Godzin, 12). Najwłaściwszą formą Liturgii Godzin jest odprawianie jej w zgromadzeniach duchownych lub zakonników; jest bardzo pożądane, aby dołączali się wierni świeccy.

Liturgia Godzin, którą nazywa się także Bożym Oficjum lub Brewiarzem, nie traci swojej wartości, gdy ktoś odmawia ją sam i to niejako „prywatnie”. „Modlitwy te odbywają się prywatnie, ale nie proszą o sprawy prywatne" (Gilbertus de Holland, Sermo XXIII in Cant., [w:] PL 184, 120).

Także w tego rodzaju okolicznościach modlitwa nie jest sprawą prywatną, lecz należy do publicznego kultu Kościoła, ponieważ wykonując ją sługa Boży spełnia swój kościelny urząd. Kapłan lub diakon, który w zaciszu kościoła lub oratorium, a nawet w swoim domu zajmuje się odprawieniem Bożego Oficjum, także bez obecności innych, spełnia dzieło w pełni ko- 
ścielne, modli się w imieniu Kościoła, za Kościół, co więcej, za całą rodzinę ludzką. Pontyfikat Rzymski zawiera pytanie:

„Czy chcecie zachowywać i pogłębiać ducha modlitwy, właściwego waszemu sposobowi życia, i w tym duchu wiernie sprawować Liturgię Godzin w intencji Kościoła i całego świata?” (por. Pontyfikał Rzymski, w obrzędzie święceń diakonatu).

A zatem w samym obrzędzie święceń diakonatu sługa Boży prosi Kościół i otrzymuje nakaz odmawiania Liturgii Godzin. Z tego powodu obowiązek odmawiania Liturgii Godzin należy do służbowych obowiązków wyświęconego i przekracza granice pobożności ściśle osobistej. Słudzy Boży razem z Biskupami złączeni są w posłudze wstawiennictwa za lud Boży im powierzony, jak Mojżesz (Wj 17, 8-16) i Apostołowie (1 Tm 2, 1-6) i sam Jezus Chrystus, „który siedzi po prawicy Ojca i wstawia się za nami” (Rz 8, 34). To samo stwierdza się w Ogólnym wprowadzeniu do Liturgii Godzin nr 108:

„Psalmy odmawia się w Liturgii Godzin nie tyle we własnym imieniu, ile w imieniu całego Kościoła Chrystusowego, a nawet utożsamiając się z Chrystusem".

Ogólne wprowadzenie do Liturgii Godzin nr 29 zawiera następujące polecenia:

„Kościół powołał biskupów, kapłanów i diakonów do sprawowania Liturgii Godzin. Powinni więc oni codziennie wypełnić w całości ten obowiązek, przestrzegając, o ile to możliwe, odmawiania poszczególnych Godzin w odpowiedniej porze dnia”.

Kodeks Prawa Kanonicznego kan. 276, 2, nr 3 tak postanawia:

„Kapłani a także diakoni przygotowujący się do prezbiteratu mają obowiązek odmawiać codziennie Liturgię Godzin, zgodnie z własnymi i zatwierdzonymi księgami liturgicznymi; natomiast diakoni stali mają odmawiać jej część, określoną przez Konferencję Episkopatu”.

Mając to przed oczyma, można odpowiedzieć na postawione pytania następująco:

1. Jakie jest zdanie Kongregacji Kultu Bożego i Dyscypliny Sakramentów co do rozciągłości obowiązku codziennego odprawiania albo odmawiania Liturgii Godzin?

Odp. Wyświęceni diakoni i kapłani są moralnie zobowiązani do odprawiania lub odmawiania całego i codziennego Bożego Oficjum na mocy przyjętych święceń, jak to wynika z obrzędu święceń diakonatu i kanonicznie jest ustalone w wyżej wymienionym kanonie 276, 2, nr 3 Kodeksu Prawa Kanonicznego. To odmawianie nie ma charakteru prywatnej pobożności, ani pobożnego nabożeństwa wybranego z własnej woli przez duchownego, lecz jest aktem własnego świętego urzędu i obowiązkiem pasterskim. 
2. Czy obowiązek odmawiania pod grzechem ciężkim odnosi się do recytacji całego Oficium Bożego?

Odp. Należy mieć przed oczyma następujące zasady:

a) poważna przyczyna, słabe zdrowie, służba duszpasterska, pełnienie miłosierdzia lub zmęczenie, a nie lekka niewygoda, może uwolnić od odmówienia części, albo nawet całego Oficjum Bożego, według ogólnej zasady: prawo kościelne pozytywne nie obowiązuje, gdy zachodzi poważna przeszkoda;

b) opuszczenie całkowite albo częściowe Oficjum Bożego, ze zwykłego lenistwa albo dla niekoniecznej rozrywki, nie jest godziwe, co więcej jest lekceważeniem, w miarę ciężkości materii, obowiązku służebnego i pozytywnego prawa Kościoła;

c) powodem zwalniającym od odmówienia Jutrzni i Nieszporów może być tylko sprawa większej wagi, bo te Godziny Liturgiczne są „głównymi częściami codziennego Oficjum" (KL 89);

d) jeżeli kapłan w tym samym dniu musi kilkakrotnie odprawić Mszę albo przez wiele godzin słuchać spowiedzi, albo wygłosić więcej kazań i dlatego jest zmęczony, może ze spokojnym sumieniem uznać, że ma słuszną przyczynę, aby opuścić proporcjonalną część Bożego Oficjum;

e) ordynariusz własny kapłana lub diakona może ze słusznej albo poważnej przyczyny, jeżeli taki wypadek zachodzi, dyspensować od części lub całości Bożego Oficjum, lub udzielić mu zamiany na inny akt pobożności (np. różaniec, drogę krzyżową, czytanie Pisma Świętego lub duchowne, albo modlitwę myślną odpowiednio przedłużoną itp.).

3. Jaka jest moc własna kryterium o „prawdziwości czasu” w tej kwestii?

Odpowiedź wymaga oddzielnych części, dla różnych wypadków.

a) Godzina Czytań nie jest ściśle związana z określonym czasem i dlatego może się odbyć o jakiejkolwiek rozumnej godzinie, może zaś być opuszczona, jeżeli zachodzi jedna z przyczyn, które były wyżej wymienione w numerze 2. Według zwyczaju Godzinę Czytań można odprawić w dniu poprzednim po odprawieniu Nieszporów, w godzinach wieczornych lub nocnych (por. Ogólne wprowadzenie do Liturgii Godzin, 59).

b) To samo należy powiedzieć o modlitwie w ciągu dnia. Ponieważ nie jest wyznaczony dla niej określony czas, należy ją odbyć w czasie między Jutrznią i Nieszporami. Poza chórem „można wybrać jedną z trzech Godzin odpowiadającą danej porze dnia, aby w ten sposób zachować tradycję modlitwy w ciągu dnia i pośród pracy” (Ogólne wprowadzenie do Liturgii Godzin, 77).

c) Zasadniczo Jutrznię należy odmówić w godzinach rannych, Nieszpory zaś w godzinach wieczornych, jak same nazwy wskazują. Jeżeli jednak ktoś nie mógł odmówić Jutrzni w godzinach rannych, ma ją odmówić, gdy będzie mógł. Podobnie z Nieszporami. Innymi słowy przeszkoda w zachowaniu 
„prawdziwości godzin” nie jest przyczyną zwalniającą od odmówienia Jutrzni i Nieszporów, ponieważ chodzi o „główne Godziny” (KL 89), które „mają wielkie znaczenie” (Ogólne wprowadzenie do Liturgii Godzin, 40).

Kto chętnie wypełnia obowiązki i chce ochoczo oddać chwałę Stwórcy wszechświata, może po hymnie Godziny wypadającej dodać przynajmniej psalmodię Godziny opuszczonej i po jednym krótkim czytaniu i modlitwę zakończyć.

Te odpowiedzi zostały ogłoszone za zgodą Kongregacji ds. Duchowieństwa.

Z Watykanu, dnia 15 listopada A.D. 2000

Grzegorz A. kard. Medina Estévez prefekt

$\dagger$ Franciszek Pius Tamburrino sekretarz

W zwiazku z licznymi pytaniami w sprawie obowiązku odmawiania Liturgii Godzin redakcja przypomina dekret Kongregacji Kultu Bożego i Dyscypliny Sakramentów w thumaczeniu o. Franciszka Małaczyńskiego OSB wyjaśniający tę sprawę. 